\title{
Die Herontdekking van George Berkeley in kontemporêre Britse Filosofie
}

\author{
A J ANTONITES \\ Ten geleide \\ Prof Dr P D Dreyer
}

Met hierdie artikel wil die skrywer ook sy hulde en dank bring aan 'n groot filosoof en leermeester, prof dr PS Dreyer, by geleentheid van sy jubileumjaar aan die Universiteit van Pretoria.

Daar is talle dissiplines in die wysbegeerte waar hy ' $n$ belangrike bydrae gelewer het. Ander weer het hy aan die Universiteit gevestig en deur sy arbeid 'n weg voor gebaan waaruit sy studente ryklik kon put. Verder wil hy altyd en moedig hy ook sy studente aan om krities-selfstandig te dink, wat so belangrik in 'n wetenskap soos die filosofie is.

Een van die dissiplines wat hy gevestig, opgebou en die weg voor gebaan het, is die wetenskapsleer en kennisleer. Hierdie artikel is die gevolg van kenteoretiese besinning.

\section{Inleiding}

Hierdie artikel wil aantoon hoedat die Britse filosofiese denke van hierdie eeu begin het by nie-empiriese denke en toe uiteindelik so ontplooi het dat die filosofie van George Berkeley herontdek is. In werklikheid verwys ons veral na net een, maar tog baie belangrike, aspek van Berkeley se denke. Dit beteken ook dat ons ons hoofsaaklik sal bepaal by die denke van Bertrand Russell en WV Quine. Inhoudelik sal dit dan primêr gaan om die problematiek van die "besondere", wat in die Britse denke die "particular" genoem word. Ons gaan dus nie 'n kronologiese weergawe gee van Russell en Quine se studie van ontwikkeling nie, maar veral van die inherente ontplooiing van die betrokke aangeleentheid.

Tog wil ons wys op die drie fases in Russel se denke volgens die indeling ER Eames ${ }^{1}$. Die eerste fase het werke ingesluit soos The Problems of Philosophy, Mysticism and Logic en Our Knowledge of the External World. Die tweede fase behels: The Philosophy of Logical Atomism, The Analysis of Mind en The Analysis of Matter. Die derde sluit veral An Inquiry into Meaning and Truth asook Human Knowledge - Its Scope and Limits in. 
Russell se denke had 'n heel nie-empiriese vertrekpunt. Dit was die tyd van die Britse realisme, op welke standpunt hy gestaan het voor 1900. Vanweë die belangstelling in die wiskunde en logika, asook die invloed van Moore, begin hy mettertyd sy eie benadering ontwikkel en kry ons sy teorie bekend as die logiese atomisme. Ons het te doen met ' $n$ denke wat kenmerke het van die empirisme, maar ook Platonisme, tesame met 'n logisisme.

\section{Kenteoretiese en Ontologiese Oorwegings}

Reeds in sy vroeë werke word dit duidelik dat die kenteoretiese relasie en die verband met die ontologiese ' $n$ probleem is. Kennis volgens die tradisionele empirisme is gewoonlik' $n$ kwessie van sintuiglike indrukke wat afkomstig is van fisiese objekte buite die subjek. Die indrukke word geassosieer en deur abstraksie en veralgemening word gekom tot kennis. Dis slegs fisiese besonderes (particulars) wat uiteraard korreleer met die sintuiglike indrukke. Vir Russell is al die komponente problematies: Fisiese objekte, sintuiglike data en besonderes. Anders as die tradisionele Britse empiriste, insluitende Berkeley, ken hy ook deurlopend realiteit toe aan universeles.

Nogtans fundeer hy kennis wel in die empiriese, maar ons merk beslis ' $n$ duidelike omsigtigheid en versigtigheid ten opsigte van ' $n$ kenteoretiese realisme. Neem byvoorbeeld die volgende: "I believe that common sense is right in regarding what we see as physical and (in one of several possible senses) outside the mind, but is probably wrong in supposing that it continues to exist when we are no longer looking at it ... I believe that the actual data in sensation, the immediate objects of sight or touch or hearing, are extramental, purely and physical, and among the ultimate ${ }^{2}$ en "Our data now are primarily the facts of sense ( $\mathrm{i}$ e of our own sense data) and the laws of logic." ${ }^{3}$

Nou is dit die sintuie wat vertroudheid (acquaintance) gee aan besonderes. Dis wel 'n twee-term relasie waar die objek genoem kan word, maar nie bevestig kan word nie. Solank hulle data is, is sintuiglike data daar en hulle voorsien die kenteoretiese grondslag van al ons kennis omtrent besonderes. Die feit dat hulle data is, is van bepalende belang: Besonderes wat' $n$ datum van waarneming konstitueer, is altyd sintuiglike data. Hierdie data is logies onafhanklik van die menslike gees, maar is wel kousaal afhanklik van die waarnemer se liggaam.

Die wêreld bestaan uit entiteite wat volgens 'n sekere patroon georden is. Hierdie entiteite of "dinge" is die besonderes. Die patroon word weer bepaal deur die relasies onder besonderes. Hierdie opbou van die wêreld deur besonderes moet nie vergelyk word met 'n huis wat die optelsom van stene is nie. Veel eerder vergelyk be- 
sonderes met die note van 'n simfonie, wat elk vir'n kort tydjie duur. Hulle volg mekaar op soos die note van die simfonie. Net so bestaan 'n fisiese ding uit besonderes wat gekorreleer is. Hulle is lede van die ding soos lede van 'n klas. So byvoorbeeld sal die verskillende besonderes wat lede is van die klas "son", met mekaar gekorreleer wees deur 'n sekere kontinuiteit en sekere intrinsieke wette van variasie. Hierbenewens is hul gekorreleer met ander besonderes wat nie lede van die klas is nie. Met ander woorde 'n fisiese ding word gedefinieer deur kontinuïteit en korrelasies, waar die "ding" dan as't ware gedissekteer is in reekse of klasse van besonderes. ${ }^{5}$

Daar is dus skynbaar nie sprake van 'n onderliggende draer van die besonderes nie. Met ander woorde substansie in die tradisionele sin van die woord tref ons nie hier by Russell aan nie. ${ }^{4}$ Tog het iets van die substansie oorgebly, soos blyk uit die kontinuïteit en die "konstantheid" waarna die sintuiglike data verwys.

Tog bly dit 'n vraag: Waarin is die konstantheid of duursaamheid van die besonderes geleë? Waar lê die verskil tussen die data en die fisiese objek? In hoeverre is die data subjektief en onafhanklik van die objek? Uit bogenoemde blyk dit dat die besonderes verband het met die fisiese objekte self.

Nou merk ons egter dat hy sensibilia onderskei van sintuiglike data. Sensibilia is die naam van fisiese objekte, maar sonder dat hulle data vir die subjek is. Sensibilia word sintuiglike data deurdat 'n verhouding van vertroudheid sy toetrede maak.

Wat egter opvallend is, is dat dieselfde sintuiglike data nie subjektief is nie: Die subjek het nie deel daaraan soos in die geval van wense en oortuigings nie. Inteendeel, Russell sê dat hulle fisies is. Dit is dus nie geestelik (mental) nie, al is dit so dat hulle nie voortduur nadat hulle opgehou het om data te wees nie. Die sintuiglike data is die besondere waarvan die subjek bewus is. Die besondere het dan ook verband met genoemde data.

Wat nou problematies is, is dat hier skynbaar twee "vlakke" besonderes is: die eenvoudige fisiese objekte self en die data. En verder: die sensibilia is wel onafhanklik van die data, maar ook dit is nog nie die ding self nie. Wel sê Russell dat die sensibilia die pad oopmaak na die "ding" of die "materia" self. Dit lyk of Russell deurgaans versigtig is om die substansie-kategorie te vermy. Die probleem is net dat dit tot 'n regressie kan lei. Dieselfde geld ten opsigte van die ander rigting na die subjek se kant toe. Hier onderskei hy weer "sensation" van sintuiglike data. Eersgenoemde is wel subjektief-geestelik en impliseer die subjek se bewus-wees van sintuiglike data. Ten opsigte van "die ding" self sê Russell dat dit die klas van sy verskynsels is. Die verskynsels weer is die sensibilia èn sintuiglike data tesame. Ons merk dus dat die fisiese ding sy verskynsels is. Ons sien ook hoe naby dit kom aan die "esse est percipi" van Berkeley. "I 
do not see how to refute it, though temperamentally I find it repulsive".8. Ons moet onthou dat die besonderes van sintuiglike data vir Russell "bestaandes" is. Net so wys Berkeley daarop dat "I do not argue against the existence of any one thing that we can apprehend either by sense or reflection. That the things I see with my eyes and touch with my hands do exist, really exist, I make not the least question. The only thing whose existence we deny is that which philosophers call matter or corporeal existence ... If any man thinks this detracts from the existence or reality of things, he is very far from understanding what hath been premised in the plainest terms I could think of."

Desondanks veronderstel Russell wel "iets" wat onafhanklik van waarneming is. Die vraag bly egter: Wat is die "iets" en wat is fisiese sintuiglike data? Laat ons verder gaan.

\section{Eiename en Beskrywings}

Hoe is ons bekend met fisiese objekte? Ons is vertroud met sintuiglike data, maar nie met die objekte self nie. Vertroudheid is volledig ' $n$ relasie en daar is geen sprake van geesteskomponente soos idees nie. Ons is bekend met die objekte slegs deur beskrywings. ' $n$ Defenitiewe beskrywing het altyd die vorm van "so-en-so". Dit verwys na een enkele objek. Daar is net èèn objek wat die "so-en-so" is. As ons sou sê "a is die so-en-so" beteken dit a het die eienskap so-en-so en niks anders het dit nie. Dit beteken weer dat ons beskrywings gebruik in die plek van eiename. ${ }^{8}$ Eiename is weer verwysings na besonderes. Eiename is woorde wat nie eienskappe of kwaliteite toeken aan 'n objek nie, maar wat dit enkel en alleen benoem. Daar is streng gesproke net twee woorde wat eiename van besonderes is $\mathrm{t} w$ "hierdie" en "ek".

Maar ons kennis omtrent die ding wat beskryf word, volg nie bloot logies uit die beskrywings self nie. Op een of ander manier moet ' $n$ beskrywing wat van toepassing is op ' $n$ besondere, ' $n$ verwysing behels na 'n besondere waarmee ons in die relasie van vertroudheid staan. ' Byvoorbeeld "Parys is die hoofstad van Frankryk". "Parys" is die denotasie en die kompleks: "Die hoofstad van Frankryk" is die betekenis van die kompleks. ' $n$ Denotasie is per definisie: As ons weet "a is so-en-so" en niks anders nie, dan is a die denotasie van die frase "die so-en-so". Met uitsondering van eiename is denotasie nie ' $n$ konstituerende deel van proposisie nie - 'n Mens kan onder meer die proposisie ken sonder om vertroud te wees met die denotasie. Dikwels is die beskrywing selfs ' $n$ middel om by die denotasie uit te kom. Om so 'n proposisie te verstaan, is vertroudheid dus nodig met die konstituente van die beskrywing. 


\section{Oorgang na veranderlikes}

Tot sover het Russell die metode gevolg van analise. Feite is gestel in proposisies. Nou gaan Russell van die standpunt uit dat 'n logikataal 'n volmaakte taal is wat tewens die essensie konstitueer van enige taal. Ons gaan nie nou in op alles met betrekking tot die taal self nie, maar laat ons ter sake stel dat veranderlikes die sintaksis van die taal is. Dis die moderne logika van kwantifiseerders waar ons te doen het met bestaans- en algemene voorvoegsels, soos Ex ensovoorts. Die bestaansveranderlikes kan na besonderes verwys.

Dit bring Russell nou om wat ons vantevore bespreek het in verband te bring met die logika. Dit is so dat formele logika nie gebruik maak van name ne, juis omdat sy proposisies slegs veranderlikes bevat. Een van die beginsels in die logika is dat as $x$ waar is vir elke waarde van $x$, dan is fa waar, waar a enige konstant is. Ons sê hier konstant, maar in werklikheid is dit geen konstant nie, want enige konstant is vir die logika 'n veranderlike. Ons noem dit so as 'n toepassing, waar konstantes met veranderlikes vervang kan word. Toegepaste logika bestaan juis in die vervanging van konstantes met veranderlikes. Dan blyk dit dat "eiename" wel "konstantes" is wat as veranderlikes gebruik kan word.

Nou kan "die so-en-so" van die vorige paragraaf omgesit word in 'n logiese proposisie, waar "die so-en-so" die grammatiese subjek was van wat nou 'n logiese veranderlike word. Dan kry ons 'n proposisie met die vorm "Daar is iets wat alleen so-en-so is", en dat ' $n$ iets wel so-en-so is. Dan word dit " $x$ is so-en-so en niks anders en $x$ is soen-so is bevoeg tot waarheid." Nou kan die saak logies sy gang rustig verder gaan en kom dit dan by die kwessie van kwantifikasie, waar ons te doen het met sommige, enige en almal se betekenisse.

Die beskrywing word dus opgebreek, veranderlikes ingevoer en proposionele funksies word die uiteindelike onderwerpe. Uiteindelik verwys dit na eenvoudige besonderes wat in ooreenstemming met die logiese atomisme gereduseer kan word tot laaste en mees eenvoudige feitelike atome as besonderes. Ten tweede verwys dit ook na universeles wat egter buite die bestek van hierdie artikel is. Dit sal vanself blyk dat dié eenvoudige atome problematies word as ons kom by die "bondels van kwaliteite."

Feit is dat met hierdie verwikkeling eiename se voorkoms en gebruik ook problematies begin word het, en die vraag ontstaan of dit nog enigsins gehandhaaf kan word. Eiename het vervat geraak in beskrywings, wat een of ander "hierdie" behels. Die besondere waarna die "hierdie" verwys het, het intussen ook 'n verdere ontwikkeling ondergaan. Laat ons daarna kyk. 


\section{Besondere word meer kompleks}

Reeds in ons bespreking oor sintuiglike data, sensibilia en die fisiese "ding" het ons afgekom op die probleem van wat die besondere daar is. Hier het nou 'n ander verwikkeling rondom die besondere ingetree.

In aansluiting by Leibniz meen Russel dat 'n besondere gekonstitueer word deur kwaliteite. Die vraag is nou hoe so 'n kompleks van kwaliteite verstaan moet word sonder dat daar teruggeval word op die ou substansie-begrip met sy ondersteunende draer. En tog wil Russell 'n vaste "iets" behou. Dit doen hy deur te soek na "iets" wat nie herhaal sal kan word nie. Dit loop uit op Russeil se kompleks van "saam-teenwoordigheid" (compresence). Dit is 'n kompleks van kwaliteite, maar die basis hiervan is nie 'n substansiële iets nie, maar die waarnemer.

Wat is 'n saam-teenwoordigheidsrelasie? As ek iets sien en terselfdertyd iets anders hoor, dan is dit 'n saam-teenwoordigheidsrelasie. Nou kan daar'n hele groep van ervarings wees wat saam-teenwoordig is. Ons merk dat die faktor van tyd hier 'n rol speel en die besondere dus meer "dinamies" word. So 'n saamteenwoordigheidskompleks het twee eienskappe: (1) Al die lede van die groep is saam-teenwoordig. (2) Niks buite die groep is saam-teenwoordig met al die lede van die groep nie. ${ }^{10} \mathrm{Dis}$ 'n volledige kompleks van saam-teenwoordigheid. Enkele van die kwaliteite of items van die saam-teenwoordigheid kan uiteraard dikwels voorkom en is nie essensieel gebonde aan ' $n$ tyd nie. Die kompleks as sodanig is iemand se totale momentale ervaring.

Daar is geen logiese en empiriese grond waarom so 'n kompleks nie sig weer kan herhaal nie. Maar omdat dit empiries so ontsettend onwaarskynlik is, meen Russell dat ons vir alle praktiese doeleindes wel sy eenmaligheid kan aanvaar. Elke sodanige kompleks is dus 'n unieke tydelike-ruimtelike posisie. Dis tweërlei uniek: (1) Persoon a sal nie so 'n momentele ervaring identies beleef nie; (2) Geen persoon b, c, d of wie ookal se dergelike geplaasde belewenis kan ooit dieselfde wees as die betrokke een van a nie. Saam-teenwoordigheid is dus ' $n$ relasie wat geldig is tussen twee of meer kwaliteite as een persoon hulle gelyktydig ervaar. So 'n volledige groep van kwaliteite konstitueer en definieer 'n enkele komplekse geheel van saam-teenwoordigheid. Dis 'n struktuur wat saamgestel is uit geestelike (mental) momente. Dit is "iets" wat bestaan nie net bloot omdat sy konstituente bestaan nie, maar omdat hulle saam-teenwoordig is - daarom konstitueer hulle 'n enkele struktuur. Dit is wel 'n eenheid, maar nie 'n klas nie.

Ons moet miskien noem dat Russell stel dat komplekse van saamteenwoordigheid gekonstrueer kan word waar daar geen waarne- 
mers is nie, byvoorbeeld deur kameras en diktafone. Die vereiste is dat dit slegs in een tyd en plek moet gebeur. 'n Mens kan ook'n kompleks waarneem sonder dat hy bewus is van al sy dele. ${ }^{11}$

So 'n kompleks kan aangedui word met "hierdie". Maar eiename is nie meer nodig vir so ' $n$ kompleks nie. Die geheel kan altyd beskryf word deur sy konstituente, en as ons nie al die konstituente ken nie, is dit 'n kwessie van onkunde wat aangevul word, en het ons nie met iets onherleibaar te doen wat wel eiename sou vereis nie. Om teoretiese redes val eiename weg.

Al wat oorbly, is bondels van kwaliteite en relasies. Wat ons ookal mag stel in tyd of plek, is kompleks. Russell besluit dat die opvatting van eenvoudige besonderes ' $n$ fout is. ${ }^{12}$ Wat tradisioneel bekend gestaan het as besonderes, is nou vervang deur' $n$ kompleks van saam-teenwoordigheid wat nie weer herhaalbaar is nie. So 'n kompleks of selfs 'n reeks van komplekse wat kousaal met mekaar verbind is op ' $n$ bepaalde manier, was vantevore die fisiese objek waaraan konvensioneel ' $n$ eienaam toegeken word.

So het ons gesien dat eiename op tweërlei wyse verdwyn het. Eers deur die oorgang na die logika met die rol van veranderlikes en nou met die teorie van saam-teenwoordigheid.

Die belangrikste uitkoms hierin is dat een-voudige besonderes vervang word deur bondels van kwaliteite. Hiermee lyk dit tweedens of Russell nog verder wegbeweeg het van 'n substansiële fisiese ding-an-sich. Hiermee is 'n belangrike aspek van George Berkeley se denke herontdek. Laat ons Berkeley aan die woord stel: "The hardness or softness, the color, taste, warmth, figure, or suchlike qualities, which combined together to constitute the several sorts of victuals and apparel, have been shewn to exist only in the mind that perceives them. ${ }^{\prime 13} \mathrm{Op}$ 'n ander plek noem Berkeley dit wat eers as substansie bekend gestaan het, ' $n$ "combination of sensible qualities." 14

Nou is die vraag of Berkeley nie nog duideliker na vore tree wanneer die posisie in die logika nog verder opgeneem word deur $\mathrm{WV}$ Quine nie. Dit geld ook die ontologiese implikasies wat daaruit moontlik word.

\section{Eliminering van Veranderlikes}

W V Quine gaan van die standpunt uit en toon aan dat veranderlikes in beginsel ontbeerlik is. Dit wil hy doen deur ' $n$ eindige groep van ses hulp-operateurs daar te stel wat verbonde is aan predikate.

Volgens die stelsel wat veranderlikes gebruik, is daar twee stappe: Eerstens word 'n predikasie gevorm "B $\mathrm{xy}^{\prime}$ " en dan word die bestaans-voorvoeging daarop toegepas. "Sommige y is sodanig dat" (y is die veranderlike). As mens nou die proposisie wil verwerklik volgens die gebruiklike veranderlike stelsel nl " $x$ byt iets" (vir'n hond 
byt iets), dan sou mens kon stel: "Sommige $\mathrm{x}$ is sodanig dat sommige y sodanig is dat B $x y^{\prime \prime}$.

Nou wil Quine dieselfde proposisie stel deur met die veranderlike van "bestaan' weg te doen en dit met sy stelsel van predikate met hulpoperateurs te vervang. Dan onderskei hy in 'n drieposisie predikaat $F$ van distansie van vergelyking, waar die predikaat " $F$ y $z$ " dan gaan beteken dat $x$ verder is van $y$ as van $z$. Dan kan ons ' $n$ tweeposisie predikaat " $B$ " hê wat staan vir byt. Die predikasie " $B \times y^{\prime}$ " beteken dan dat $x$ vir $y$ byt. Dan onderskei hy 'n een-posisie predikaat " $D$ " vir hondheid waar $D x$ sal beteken dat $x$ ' $n$ hond is.

Nou wil Quine dit gebruik om aan te dui hoe $x$ vir iets kan byt, met sy nuwe lyn waar 'n sekere operateur op predikasie gebruik word.

Anders as wat die stelsel met veranderlike eers 'n predikasie Bscy gevorm en toe die bestaans voorvoeging "Sommige y is sodanig dat" daarop van toepassing gemaak het, gaan Quine met sy gebruik net mooi andersom: Eers vorm hy 'n nuwe predikaat, 'n een-plek predikaat wat beteken "byt iets", en dàn gebruik hy dit en " $x$ " om 'n predikasie te vorm " $x$ byt iets". ${ }^{15}$

Hiervoor is 'n operateur nodig wat van toepassing gemaak kan word op 'n twee-posisie predikaat om 'n een-posisie predikaat "byt iets" voort te bring. Hierdie operateur noem hy dan derelativisasie (Der). "Der B" is dus die een posisie-predikaat van byt of om iets te byt, en die predikasie (Der B) $x$ beteken dat $x$ iets byt.

As mens derelativisasie insgelyks van toepassing maak op ' $n$ eenposisie predikaat of sin wat doodeenvoudig bestaan bevestig, dan beteken "Der D" net dat daar honde is. Dit het dan die gevolg, die implikasie, dat aangesien "(Der B) $x$ " beteken dat sc iets byt, "Der Der B" beteken dat iets vir iets byt.

As $P$ nou enige n-posisie predikate voorstel, dan sien Deralitivisasie aldus daar uit: (Der $P$ ) $x, \ldots x_{n-1}$ as en slegs as

daar sommige $X_{n}$ is sodanig dat $P x, \ldots x_{n} \cdot{ }^{16}$

Dan ontwerp Quine ook die operateurs van inversie en refleksie. Met hierdie voorbeelde is aangetoon hoe veranderlikes uitgeskakel is. Tesame hiermee is die spreke van "bestaan" ook uitgeskakel, d w s "bestaan" met sy veranderlike word uitgekskakel. M a w - Logika kan oor die weg kom sonder veranderlikes.

As dit so is dat ook "bestaan" langs logiese weg ontbeerbaar geword het vanweë Quine, en "hierdie" as 'n eenvoudig besondere ewe-eens ontbeerbaar word vanweë Russell, dan is al wat oorbly, 'n kompleks van sintuiglike kwaliteite. So het kontemporêre Britse denke deur sy eie inherente ontwikkeling gelei tot die oopdekking van Berkeley. 
Weer eens lyk dit of ons baie naby aan Berkeley se esse est percipi gekom het, maar dan sê Quine in 'n voetnota: "... whereas ours make no ontological demands, being even retranslatable into 'not' 'and', and existence prefixes." ${ }^{17}$ Volgens hom het Schönfunkel in 1924 die eerste poging aangewend tot die eliminasie van veranderlikes, en hy het wel ontologiese implikasies daaruit getrek, deurdat hy 'n abstrakte heelal voorveronderstel het wat is: "equivalent to that of higher set theory ..."18

\section{Slot}

Wie sou nou kon dink dat ' $n$ klein sakie soos besonderes tot sulke ingrypende en diepgaande arbeid kon lei? Dit laat mens dink aan Russell se woorde wat sekerlik nie net van toepassing is op sy eie denke nie, maar op filosofering in die algemeen: "The point of philosophy is to start with something so simple as not seen worth stating, and to end with something so paradoxical that no one will believe it."19

1. E R Eames, Bertrand Russell's Theory of Knowledge, $\mathrm{p} 96$.

2. Russell, B, Mysticism and Logic, p 127, 128.

3. Russell, B, Our Knowledge of the External World, p 79.

4. Russell, B, The Analysis of Matter, p 238-248.

5. Russell, B, Mysticism and Logic, p 127-127.

6. Russell, B A W, The Autobiography of Bertrand Russell, vol II, p 194, Uit Tipton IC, Berkeley, p 15.

7. Berkeley, George, Concerning Human Understanding; Uit: The English Philosophers From Bacon to Mill, p 534.

8. Russell, B, Mysticism and Logic, p 214-215.

9. Russell, B A W, Mysticism and Logic, p 216.

10. Russell, B, Human Knowledge - Its Scope and Limits, p 98.

11. Russell, B, Human Knowledge - Its Scope and Limits, p 87-99.

12. Russell, B, Human Knowledge - Its Scope andLimits, p 87-99.

13. Berkeley, G, Concerning Human Understanding, Uit English Philosophers, p 535.

14. Ibid, p 534 .

15. Quine, WV, Selected Logic Papers, p 229, 230.

16. Ibid, p 230, 231.

17. Ibid, p 233.

18. Ibid.

19. Warnock, GJ, English Philosophy Since 1900, p 27.

\section{Verdere Bronne gebruik}

1. Russell, B; The Analysis of Mind; George Allen and Unwin Ltd., London.

2. Russell, B; An Inquiry Into meaning and Truth; George Allen and Unwin Ltd., Londen.

3. Russell, B; The Analasis of Matter; Kegan Paul, Trench, Trubner and Co Ltd, Londen.

4. Van Iten, RJ; The Problem of Universals; Appleton-CenturyCrofts; Meridith Corporation; New York.

5. Bell, DR; Bertrand Russel, Makers of Modern Thought; Judson Press; Pennsylvania. 